\title{
Analysis of the action of Himatanthus drasticus in progression of urethane-induced lung cancer in mice
}

\author{
Análise da ação da Himatanthus drasticus na progressão do câncer de pulmão induzido por \\ uretana em camundongos
}

\begin{abstract}
Wendy Caroline de Souza Costa França ${ }^{1}$, Ana Cláudia Rodrigues Lopes Amaral de Souza ${ }^{1}$, José Antônio Cordeiro ${ }^{1}$, Patricia Maluf Cury ${ }^{1}$
\end{abstract}

\begin{abstract}
Objective: To evaluate the effect of janaguba in inhibiting the development of lung cancer in an experimental urethane-induced model. Methods: a total of $3 \mathrm{mg} / \mathrm{kg}$ urethane was injected in 51 Balb-C mice aged 7-13 weeks of life. Janaguba was administered orally daily in two doses: $0.04 \mathrm{~mL}$ (Group 2, G2) and $0.06 \mathrm{~mL}$ (Group 3, G3), for 20 weeks. After this period, the mice were sacrificed and the number of lesions counted. Results: The mean weight of Group 2 was lower than that of Group 3, and that of Group 1 (Control, G1) (G1 = $35.533 \mathrm{~g}$; $\mathrm{G} 2=33.359 \mathrm{~g} ; \mathrm{G} 3=37.125 \mathrm{~g}$ ). The number of nodules did not differ between groups (mean $\mathrm{G} 1=\mathrm{G} 2=\mathrm{G} 3=1 ; \mathrm{p}=0.88$ ). Conclusion: Janaguba had an effect on the growth of mice, but had no influence on the progression of lung cancer in this model.
\end{abstract}

Keywords: Lung neoplasms; Mice; Urethane; Phytotherapy, experimental

\section{RESUMO}

Objetivo: Avaliar a ação da janaguba na inibição do desenvolvimento de câncer de pulmão em modelo experimental induzido por uretana. Métodos: Foram injetados $3 \mathrm{mg} / \mathrm{kg}$ de uretana em 51 camundongos Balb-C , com 7 a 13 semanas de vida. Janaguba foi administrada via oral diariamente em duas doses: 0,04 mL (Grupo 2, G2) e 0,06 mL (Grupo $3, G 3)$, por 20 semanas. Após esse período, os camundongos foram sacrificados e o número de lesões, contado. Resultados: A média de peso do Grupo 2 foi menor que a do Grupo 3, e que a do Grupo 1 (Controle, G1) (G1 $=35,533 \mathrm{~g} ; \mathrm{G} 2=33,359 \mathrm{~g}$; $\mathrm{G} 3=37,125 \mathrm{~g}$ ). 0 número de nódulos não diferiu entre os grupos (média $\mathrm{G} 1=\mathrm{G} 2=\mathrm{G} 3=1$; $p=0,88$ ). Conclusão: $A$ janaguba apresentou um efeito no crescimento dos camundongos, mas não apresentou influência na progressão do câncer de pulmão neste modelo.

Descritores: Neoplasias pulmonares; Camundongos; Uretana; Fitoterapia experimental

\section{INTRODUCTION}

Currently lung cancer is the most frequent cause of death related to neoplasms in both sexes, and its incidence ranks first in malignant neoplasms (approximately 1.2 million new cases in the world) $)^{(1)}$. In the male population, smoking is responsible for over $80 \%$ of diagnosed cases of lung cancer; among women, $45 \%$ of cases of lung cancer are attributed to smoking ${ }^{(1)}$. Diagnosis is most often made when the tumor is in stage III or IV, with metastasis, since the initial tumors do not usually produce symptoms that justify investigation, what leads to poor prognosis for most of these patients. This indicates the need for early detection measures, considering that surgical resection, the only therapeutic approach that provides potential cure today, is effective only in early clinical stages ${ }^{(2)}$.

Janaguba is a plant of the genre Himatanthus, of the family of Apocynaceae. This genre is distributed in tropical and subtropical regions of South America, has 13 species and comprises 8 varieties. Chemical studies showed the presence of depsides, terpenes and iridoids in Himatanthus sucuuba (Spruce) Woodson ${ }^{(3)}$. Some pharmacological studies showed the anti-inflammatory and analgesic actions of the iridoids present in the bark of its stem and in latex ${ }^{(4)}$, the healing effect and a low reproductive and teratogenic toxicity in female rats, indicating that its consumption is safe in humans in treating gastritis and hemorrhoids ${ }^{(5)}$.

Among the iridoids found, fulvoplumierin, isoplumericin and plumericin have proven antineoplastic, anti-inflammatory and antimicrobial actions. The isolate depsides of $H$. sucuuba act as inhibitors of the

\footnotetext{
Study carried out at Faculdade de Medicina de São José do Rio Preto - FAMERP, Sao Jose do Rio Preto (SP), Brazil.

1 Faculdade de Medicina de São José do Rio Preto - FAMERP, Sao Jose do Rio Preto (SP), Brazil.

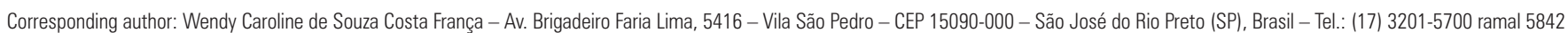
- E-mail:wendyfranca@gmail.com

Received on: March 16, 2011 - Accepted on: Sep 13, 2011

Conflicts of interest: none
} 
enzyme beta monoamino-oxidase (MAO-B) ${ }^{(3)}$. Souza et al., in 2006, proved the immunoregulation action of the H. sucuuba in vitro on nitric oxide and interferon gama, suggesting this is the path for anticancer action ${ }^{(6)}$.

Urethane, an ethylic ester of carbamic acid, is a carcinogen widely used in experimental chemical carcinogenesis studies and develops, for example, lung adenocarcinomas in mice ${ }^{(7,8)}$. It can be administered orally or by injection, and is an adequate carcinogen to produce tumors in a short period of time. Moreover, it has low toxicity, leading to reduced mortality rate of animals. In previous studies, the effects of air pollution in lung cancer were analyzed in an experimental model in mice (7,8). $^{(2)}$

\section{OBJECTIVE}

To assess the action of janaguba in development of lung cancer, in a urethane-induced experimental model.

\section{METHODS}

\section{Extraction of janaguba}

The product prioritized for the present study, as mentioned above, is janaguba milk (Himatanthus drasticus), which was collected by a specialized supplier from Serra do Araripe (CE), according to orientations of the Instituto Brasileiro do Meio Ambiente (IBAMA). It is the stem latex with water (used when extracting the latex from the plant).

From this "milk", as it is commonly called, the extraction process was performed with organic solvents and purification, until obtaining an amorphous powder to better study the compound, at Universidade Federal do Ceará (UFC).

To this end, the extraction of milk was made with ethyl acetate and using a funnel for separation. Five successive extractions were carried out. Ethyl acetate extract was evaporated at room temperature and later submitted to flash chromatography of corn starch under pressure, and using dichloromethane/acetone as eluent, in increasing polarity. A whitish solid (HD) with high yield (HD) was obtained (1 L of milk - $10 \mathrm{~g}$ ). This solid was submitted to purification in a silica column, and using hexane/ dichloromethane/ as eluent, in increasing polarity.

Since it was not possible to reproduce this technique at our institution (Faculdade de Medicina de São José do Rio Preto - FAMERP), only the milk provided by the Department of Pharmacy/Pharmacognosia Laboratory, UFC, was utilized

\section{Procedures}

Initially 51 Balb-c mice aged 7 to 13 weeks were used. On the first day of the experiment, the animals were weighed and $3 \mathrm{mg} / \mathrm{kg}$ of urethane were injected in each animal, through a master solution of $10 \mathrm{~mL}$ of sodium chloride $(\mathrm{NaCl})$ at $0.9 \%$, intraperitoneally, fractionated into two doses of $1.5 \mathrm{mg} / \mathrm{kg}$ with an interval of 48 hours between them.

The animals were divided into three groups:

- Group 1: with 16 mice (control), received only urethane;

- Group 2: with 17 mice, received urethane and janaguba milk at the dose of $0.04 \mathrm{~mL}$ per mouse, diluted in water that was changed daily. This dose was proportionally based on the dose used in humans;

- Group 3: with 17 mice, received urethane and janaguba milk at the dose of $0.06 \mathrm{~mL}$ per mouse, diluted in water that was changed daily.

These groups were kept for 20 weeks, received feed and water (which contained janaguba milk in Groups 2 and 3). The animals were weighed weekly and the mean weight per group was recorded. The animals were kept in cages at the temperature of $23 \pm 2^{\circ} \mathrm{C}$, relative humidity of $60 \%$ and diet based in water and feed $a d$ libitum.

Twenty weeks after initiating the experiment the animals were sacrificed after inhaling carbonic gas. Later, the respiratory tract was removed and fixed by intratracheal instillation of $10 \%$ buffered formalin solution. Necropsy was performed in all animals, removing lungs and heart. The kidneys, liver and spleen were removed from the first five mice sacrificed in each group to analyze the effect of the phytotherapeutic agent in these organs. All materials were fixed in formalin for preparing the histological slides, which were stained with hematoxylin-eosin after the routine processing. The number of lesions was statistically evaluated by non-parametric methods of Kruskal- Wallis and MannWhitney.

The Project was approved by the Ethics Committee through Protocol Faculdade de Medicina de São José do Rio Preto (FAMERP) no. 6006/2008, of July 29, 2009.

\section{RESULTS}

As to weight of mice at the end of the experiment (Figure 1), there was a statistically significant difference between the mean weight in Group 2, which used the dose of janaguba equivalent to that used by humans $(0.04 \mathrm{~mL} /$ day $)$, and that of Group 3, which received a higher dose of janaguba $(0.06 \mathrm{~mL} /$ day $)$; the highest mean was in Group $3(\mathrm{G} 1=35.533 \mathrm{~g}, \mathrm{G} 2=33.359 \mathrm{~g}$, $\mathrm{G} 3=37.125 \mathrm{~g}$ ).

Regarding the number of neoplastic nodules (Figures 2 and 3 ) analyzed in the slides, there was no 


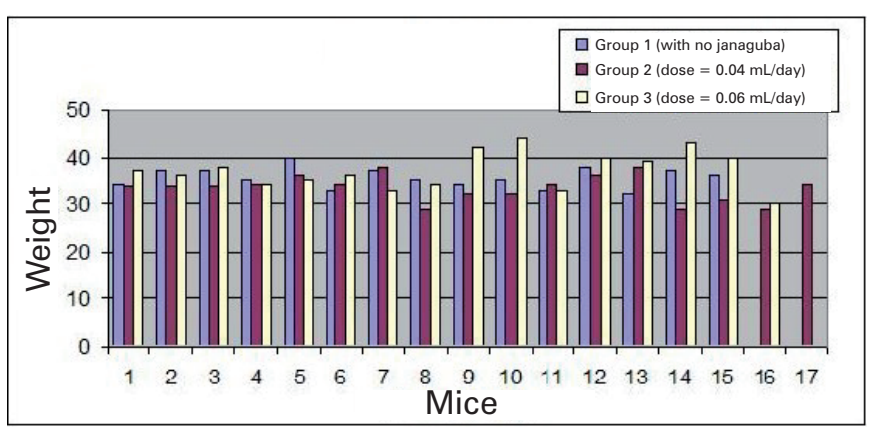

Figure 1. Mouse weight at the end of experiment per treatment received. Oneway ANOVA: weight versus treatment - there is evidence of difference between means (vp $=0.004)$ : janaguba_(Group 1) $<$ janaguba_(Group 2) (Bonferroni vp $=0.012$ )

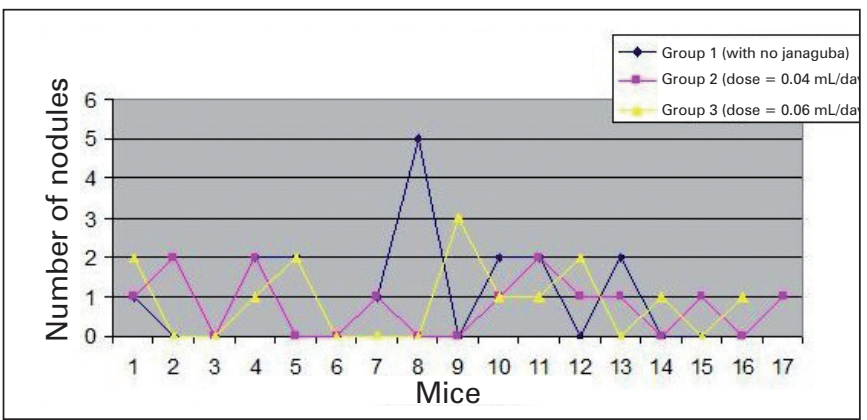

Figure 2. Number of pulmonary nodules per treatment received. Kruskal-Wallis test: number of nodules versus treatment - there is no evidence of difference $(p=0.88)$

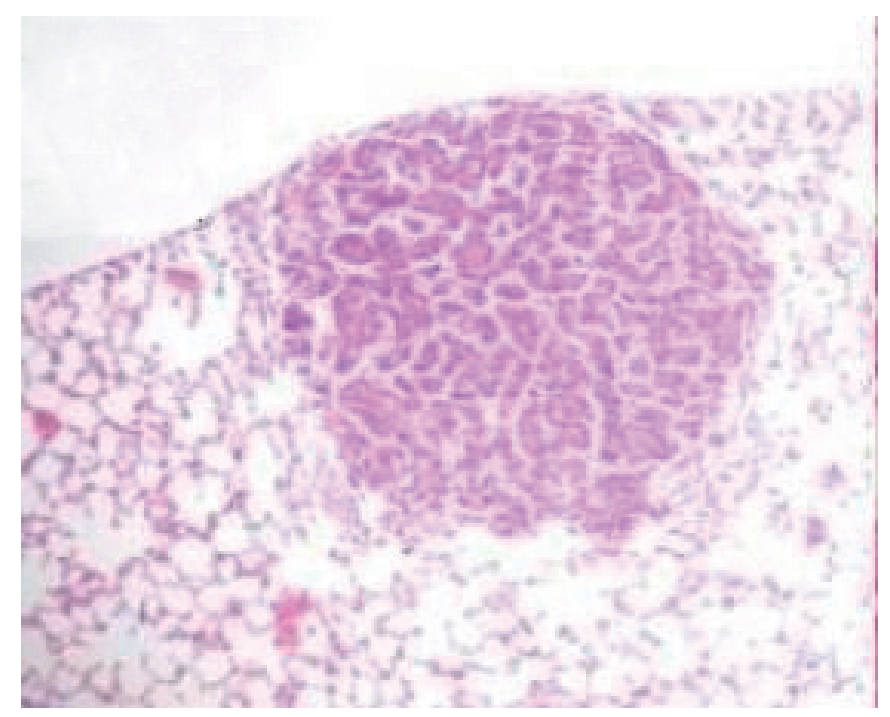

Figure 3. Photomicrography of pulmonary nodule stained by hematoxylin-eosin, $100 \mathrm{X}$

significant difference between the control group and the groups that used janaguba during the experiment (mean of $\mathrm{G} 1=\mathrm{G} 2=\mathrm{G} 3=1 ; \mathrm{p}=0.88$ ). The histological evaluation of other organs studied did not demonstrate any significant alteration.

\section{DISCUSSION}

This study demonstrated that janaguba, in both doses utilized, did not present anti-tumor effect in the model studied. There were no significant histological changes in other organs. However, it was curious to note a significant difference in weight between the groups receiving the lower and the higher dose of this phytotherapeutic agent.

This difference in weight was not observed in other experiments that used urethane to induce lung cancer. Roomi et al. used $\mathrm{A} / \mathrm{J}$ mice that were submitted to carcinogenesis by urethane and were fed with a mixture of foods containing lysine, proline, arginine, ascorbic acid, green tea extract, $\mathrm{N}$-acetylcystein, selenium, copper and magnesium, and did not observe a significant difference between weight of mice that used the mixture and the control group ${ }^{(9)}$. Similar result was found in Balb-C mice exposed to tobacco after urethane-induction of lung cancer by our group ${ }^{(10)}$.

By and large the medications currently used in treatment of cancer lead to weight loss. In a study conducted with $\mathrm{A} / \mathrm{J}$ mice on use of erlotinib after 16 weeks of urethane-induction carcinogenesis, it was verified that high doses, such as $100 \mathrm{mg} / \mathrm{kg}$, led to weight loss by 9 to $12 \%, 24$ hours after use of the drug. When decreasing the dose to $30 \mathrm{mg} / \mathrm{kg}$, weight loss was still significant after five days of treatment, and only when the researchers dropped the dose to $10 \mathrm{mg} / \mathrm{kg}$, the loss was considered non-significant, despite significant reduction in tumor burden in male mice ${ }^{(11)}$.

In our study, weight was significantly greater in the group on the higher dose of janaguba as compared to the lower-dose group. This finding can not be related to efficacy of the phytotherapeutic agent, since there was no statistical decrease in the number of nodules as compared to the control group. One of the possibilities would be a side effect of the drug, represented by generalized interstitial edema, since no other significant histological alterations in internal organs were observed.

A criticism to the present study would be no conduction of the experiment in metabolic cages. This was not initially planned since the focus of the work was to evaluate the anti-tumor effect and the analysis of the number of pulmonary lesions would be sufficient to assess such effect, as our group had already done with other drugs, such as FTY720(12,13). It is unlike that gaining weight would be related to increased intake of water, because the three groups had similar intake. A new approach to assess weight gain in animals, as well as serum protein determination, should be made.

The number of animals used was considered appropriate, since it was similar or even higher than in other studies of our group with positive results ${ }^{(12,13)}$. 
Experimental models that use urethane as carcinogen have achieved good results in chemoprevention of lung cancer. However, experiments using urethane in Balb-c mice are not often described in the current literature, and those performed at our institution are important examples ${ }^{(10,12,13)}$. A study carried out in $\mathrm{A} / \mathrm{J}$ mice with silibinin, a tumor growth inhibitor, led to a statistically significant reduction in tumor multiplicity ${ }^{(14)}$. And the use of fatty acid synthase (FAS) inhibitors led to decreased number of tumors as well as of total tumor burden in relation to the control group ${ }^{(15)}$. The mixture of foods already mentioned, also used in A/J mice, ingested for 20 weeks - the same duration of our experiment, resulted in a drop by $49 \%$ in mean number of tumors and in a reduction by $18 \%$ in mean weight of lungs in relation to the control group ${ }^{(9)}$.

Nonsteroidal anti-inflammatory drug activated gene (NAG-1) is known for inhibiting progression of gastrointestinal cancer in rats, and caused a decrease in number and size of pulmonary nodules as compared to the control ${ }^{(16)}$, in transgenic animals with urethaneinduced carcinogenesis.

An explanation for our negative finding regarding the possible anti-tumor effect of janaguba would be the fact that we used only males in our sample. The literature describes different effects of drugs in males and females in experimental models with mice. In a study conducted with $\mathrm{A} / \mathrm{J}$ mice using erlotinib for urethane-induced lung cancer, the males were more sensitive to the drug and had a significant decrease in tumor burden. On the other hand, females presented a significant increase in lesions ${ }^{(11)}$. Therefore, beside the possibility of janaguba having no anti-tumor effect in Balb-C mice, we could consider the hypothesis of male mice being less sensitive to action of janaguba, and this fact could be analyzed in future experiments with the phytotherapeutic agent in females.

\section{CONCLUSION}

Janaguba had effect on the weight gain of the Balb-C mice, demonstrated by the weight difference observed in the animals when used at diverse doses, but it did not influence in the progression of urethane-induced lung cancer in this model. It would be interesting to assess the effect of this substance by checking other doses or the use in other animal species.

\section{ACKNOWLEDGMENTS}

We are grateful to Aline Holanda Silva and Dr Mary Anne Medeiros Bandeira, from the Department of Pharmacy/Pharmacognosia Laboratory, Faculdade de
Farmácia, Odontologia e Enfermagem, Universidade Federal do Ceará - UFC, who provided the janaguba milk to conduct the experiment. We thank the National Council for Research and Development (CNPq), for the grant given by the Institutional Program of Scientific Initiation Grant (PIBIC), in 2009-2010.

\section{REFERENCES}

1. Instituto Nacional do Câncer (INCA) [Internet]. Estimativa da incidência e mortalidade por câncer no Brasil - 2008 - Introdução. [citado 2009 Maio 10]. Disponível em: www.inca.gov.br/estimativa/2008/index.asp?link=conteudo view.asp\&ID $=2$.

2. Martins RG, Advincula G, Costa R, Aragão B, Santos W, Toscano E, et al. Weekly Docetaxel as first-line chemotherapy in stage IV nonsmall cell lung cancer: effective treatment with low toxicity. Rev Bras Cancerol. 2004;50(4):279-86.

3. Silva JR, Amaral AC, Silveira CV, Rezende CM, Pinto AC. Quantitative determination by HPLC of irioids in the bark and latex of Himatanthus sucuuba. Acta Amazônica. 2007;37(1):119-22.

4. Silva JR, Rezende CM, Pinto AC, Pinheiro MLB, Cordeiro MC, Tamborini E, et al. Ésteres triterpênicos de Himatanthus sucuuba (Spruce) Woodson. Quím Nova. 1998;21(6):705-8.

5. Villegas LF, Fernández ID, Maldonado H, Torres R, Zavaleta A, Vaisberg AJ, et al. Evaluation of the wound-healing activity of selected traditional medicinal plants from Perú. J Ethnopharmacol. 1997;55(3):193-200.

6. Souza MS, Cordeiro MS, Rosasb EC, Henriquesb MG, Sianib AC. PHCOG MAG.: Research article inhibition of nitric oxide and interferon gama production by irioids and triterpenes from the roots of Himanthus sucuuba. Pharmacognosy Mag. 2006;2(8):216-9.

7. Reymão MS, Cury PM, Lichtenfels AJ, Lemos CN, Battlehner CN, Conceição GMS, et al. Urban air pollution enhances the formation of urethane-induced lung tumors in mice. Environmental Res. 1997;74(2):150-8.

8. Cury PM, Lichtenfelds AJ, Reymão MS, Conceição GM, Capelozzi VL, Saldiva $\mathrm{PH}$. Urban levels of air pollution modifies the progression of urethane-induced lung tumors in mice. Pathol Res Prat. 2000;196(9):627-33.

9. Roomi MW, Roomi NW, Kalinovsky T, Rath M, Niedzwiecki A. Chemopreventive effect of a novel nutrient mixture on lung tumorogenesis induced by urethane in male A/J mice. Tumori. 2009;95(4):508-13.

10. Santiago LN, de Camargo Fenley J, Braga LC, Cordeiro JA, Cury PM. The effect of different doses of cigarette smoke in a mouse lung tumor model. Int J Clin Exp Phatol. 2009;2(2):176-81.

11. Zerbe LK, Dweyr-Nild LD, Fritz JM, Redente EF, Shroyer RJ, Conklim E, et al. Inhibition by erlotinib of primary lung adenocarcinoma at an early stage in male mice. Cancer Chemother Pharmacol. 2008;62(4):605-20.

12. Lucas da Silva LB, Ribeiro DA, Cury PM, Cordeiro JA, Bueno V. FTY720 treatment in experimentally urethane-induced lung tumors. J Exp Ther Oncol. 2008; $7(1): 9-15$

13. Salinas NR, Oshima CT, Cury PM, Cordeiro JA, Bueno V. FTY720 and lung tumor development. Int Immunopharmacol. 2009;9(6):689-93.

14. Singh RP, Deep G, Chittezhath M, Kaur M, Dwyer-Nield LD, Malkinson AM, et al. Effect of silibinin on the growth and progression of primary lung tumors in mice. J Nat Cancer Inst. 2006;98(12):846-55.

15. Orita H, Coulter J, Tully E, Kuhajda FP, Gabrielson El. Inhibiting fatty acid synthase for chemoprevention of chemically induced lung tumor. Clin Cancer Res. 2008;14(8):2458-64.

16. Cekanova M, Lee SH, Donnell RL, Sukhthanka M, Eling TE, Fischer SM, et al. Nonsteroidal anti-inflammatory drug-activated gene-1 expression inhibits urethane-induced pulmonary tumorigenesis in transgenic mice. Cancer Prev Res (Phila). 2009;2(5):450-8. 